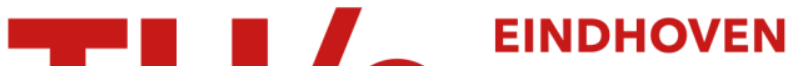 UNIVERSITY OF TECHNOLOGY
}

\section{On the formation of aluminum tungstate and its presence in tungsten oxide on gamma-alumina catalysts}

\section{Citation for published version (APA):}

Thomas, R., Kerkhof, F. P. J. M., Moulijn, J. A., Medema, J., \& Beer, de, V. H. J. (1980). On the formation of aluminum tungstate and its presence in tungsten oxide on gamma-alumina catalysts. Journal of Catalysis, 61(2), 559-561. https://doi.org/10.1016/0021-9517\%2880\%2990409-1, https://doi.org/10.1016/0021-9517(80)90409-1

DOI:

10.1016/0021-9517\%2880\%2990409-1

10.1016/0021-9517(80)90409-1

Document status and date:

Published: 01/01/1980

\section{Document Version:}

Publisher's PDF, also known as Version of Record (includes final page, issue and volume numbers)

\section{Please check the document version of this publication:}

- A submitted manuscript is the version of the article upon submission and before peer-review. There can be important differences between the submitted version and the official published version of record. People interested in the research are advised to contact the author for the final version of the publication, or visit the $\mathrm{DOI}$ to the publisher's website.

- The final author version and the galley proof are versions of the publication after peer review.

- The final published version features the final layout of the paper including the volume, issue and page numbers.

Link to publication

\section{General rights}

Copyright and moral rights for the publications made accessible in the public portal are retained by the authors and/or other copyright owners and it is a condition of accessing publications that users recognise and abide by the legal requirements associated with these rights.

- Users may download and print one copy of any publication from the public portal for the purpose of private study or research.

- You may not further distribute the material or use it for any profit-making activity or commercial gain

- You may freely distribute the URL identifying the publication in the public portal.

If the publication is distributed under the terms of Article 25fa of the Dutch Copyright Act, indicated by the "Taverne" license above, please follow below link for the End User Agreement:

www.tue.nl/taverne

Take down policy

If you believe that this document breaches copyright please contact us at:

openaccess@tue.nl

providing details and we will investigate your claim. 


\section{On the Formation of Aluminum Tungstate and Its Presence in Tungsten Oxide on $\gamma$-Alumina Catalysts}

Tungsten oxide $(1-5)$ and molybdenum oxide $(1,2,5-17)$ on $\gamma$-alumina and sulfided catalysts derived from these systems have been studied by several authors because of their interest as catalysts in reactions such as metathesis and hydrodesulfurization.

The purpose of this note is to determine whether bulk aluminum tungstate is present as a major compound in tungsten oxide on $\gamma$-alumina catalysts of practical interest. Some authors have proposed its formation (1-3), while others present data suggesting the absence of this compound $(4,5)$. The same controversy exists for molybdenum oxide on $\gamma$-alumina. Since Raman spectroscopy has proven to be a valuable tool in studies on the structure of supported catalysts $(1,4-6,15-17)$, it is applied here as the main technique.

In Fig. 1 the Raman spectra of aluminum tungstate and catalysts preparcd by wet and dry impregnation of $\gamma$-alumina (Ketjen 000-1.5E) with ammonium metatungstate (Koch-Light, 99.9\%), calcined at $823^{\circ} \mathrm{K}$, are shown. Experimental details on the Raman spectra are reported elsewhere (4). The spectrum of aluminum tungstate is characterized by a sharp band at $1046 \mathrm{~cm}^{-1}$. The spectra of the catalysts show a broad band at about $970 \mathrm{~cm}^{-1}$, which has been attributed to a polymeric, octahedrally coordinated, tungsten compound (4). The bands at 715 and $805 \mathrm{~cm}^{-1}$ are Raman bands of $\mathrm{WO}_{3}$. In these catalysts no aluminum tungstate is present in detectable amounts. Even the catalysts with a rather high tungsten content $(4-5$
$\mathrm{W}$-atoms $/ \mathrm{nm}^{2}$ ) contain no aluminum tungstate. This is in contrast to $\gamma$-aluminasupported molybdenum oxide in which aluminum molybdate has been found in catalysts with a coverage of 4.5-7 $\mathrm{Mo}-$ atoms $/ \mathrm{nm}^{2}$ (16).

Measurements on physical mixtures of aluminum tungstate and $\gamma$-alumina showed that the detection limit of aluminum tungstate in these mixtures is less than $1 \mathrm{wt} \%$. Consequently one must conclude that aluminum tungstate is not a major compound in tungsten oxide on $\gamma$-alumina catalysts. This conclusion was recently confirmed by temperature-programmed reduction measurements (18), which showed that the amount of aluminum tungstate must be considerably less than $1 \mathrm{wt} \%$.

The main arguments supporting the conclusion that tungsten oxide on $\gamma$-alumina catalysts contain aluminum tungst te are based on results obtained from Raman and luminescence spectroscopy and from activity measurements (1-3). In our opinion, however, the purity of the reference compound used in these studies was questionable. Aluminum tungstate was prepared at $823^{\circ} \mathrm{K}(16 \mathrm{hr})$ from a coprecipitate of ammonium metatungstate and aluminum nitrate, while other literature data indicate that a higher temperature is to be preferred $(19,20)$. We have checked the synthesis of aluminum tungstate by calcining a coprecipitate of aluminum nitrate and ammonium metatungstate (Baker Chemicals) at three temperatures, 823,1173 , and $1373^{\circ} \mathrm{K}$. 'The Raman spectra are shown in Fig. 2. From comparison with the spec- 
trum of tungsten oxide it is clear that the formation of aluminum tungstate is not yet completed at 823 and $1173^{\circ} \mathrm{K}$. In the spectrum of the sample calcined at $823^{\circ} \mathrm{K}$ there is a small band due to aluminum tungstate, together with two broad bands (807 and $719 \mathrm{~cm}^{-1}$ ) of tungsten trioxide. In addition there is a broad band at $980 \mathrm{~cm}^{-1}$, which is also present in the spectra of our catalysts. The sample calcined at $1173^{\circ} \mathrm{K}$ contains more aluminum tungstate, but still a considerable amount of tungsten trioxide. The system is now better defined, as can be seen from the sharpncss of the bands of tungsten trioxide and from the disappearance of the polymeric compound. This can also be concluded from the X-ray diffraction (XRD) patterns. By XRD no crystalline tungsten trioxide is observed, implying that it is

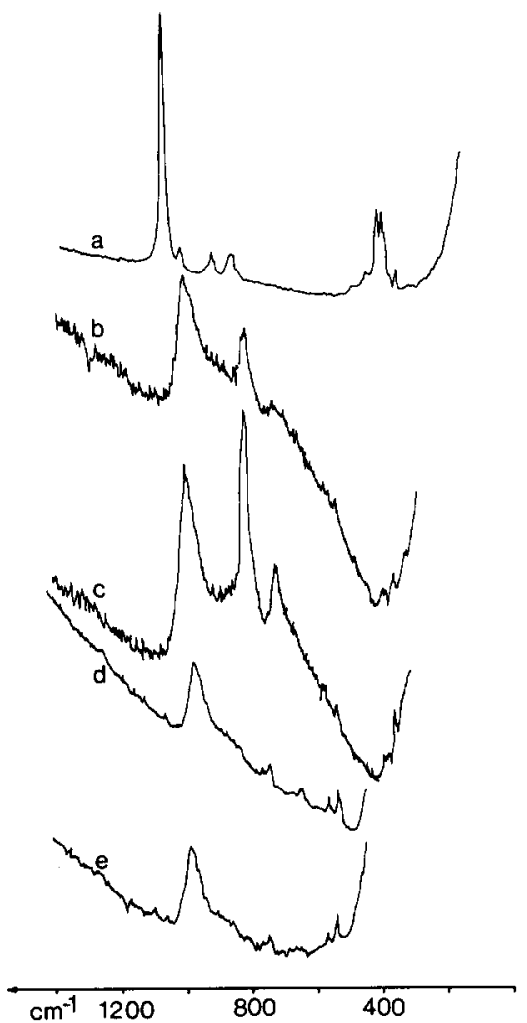

Fig. 1. Raman spectra of (a) aluminum tungstate and (b-e) $\mathrm{WO}_{3} / \gamma-\mathrm{Al}_{2} \mathrm{O}_{3}$ catalysts; (b) $25 \mathrm{wt} \%$ $\mathrm{WO}_{3}$, wet $\left(4 \mathrm{~W}\right.$-atom $\left./ \mathrm{nm}^{2}\right)$; (c) $29 \mathrm{wt} \% \mathrm{WO}_{2}$, dry (5 W-atom $/ \mathrm{nm}^{2}$ ); (d) 8 wt $\% \mathrm{WO}_{3}$, wet (1 W-atom/ $\mathrm{nm}^{2}$; (e) 7 wt $\% \mathrm{WO}_{3}$, dry $\left(0.9 \mathrm{~W}\right.$-atom $\left./ \mathrm{nm}^{2}\right)$.

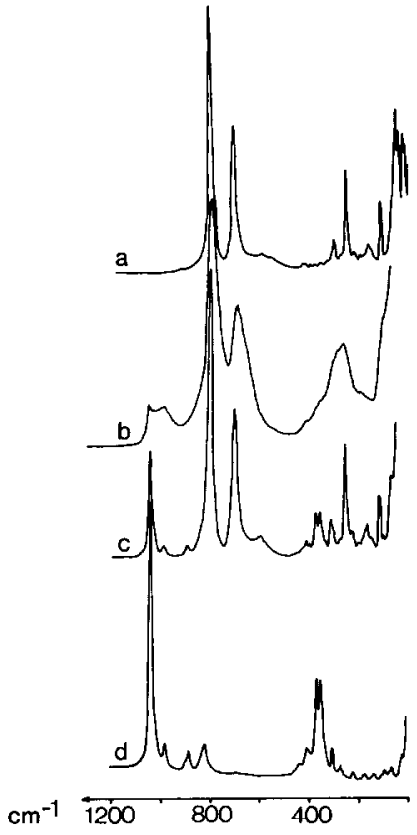

FIG. 2. Raman spectra of (a) tungsten trioxide and (b, c, d) coprecipitates of aluminum nitrate and ammonium metatungstate calcined at (b) $823^{\circ} \mathrm{K}$, (c) $1173^{\circ} \mathrm{K}$, and (d) $1373^{\circ} \mathrm{K}$.

amorphous, microcrystalline, or present in nondetectable amounts. All samples show the diffraction patterns of aluminum tungstate; the increasing sharpness of the patterns indicates a drastic increase in crystallinity when the calcination temperature is increased from 873 to $1123^{\circ} \mathrm{K}$. Further increase of the temperature does not influence the crystallinity significantly. From the XRD pattern alone it might be concluded that the transition of aluminum nitrate and ammonium metatungstate into aluminum tungstate is already complete at low temperature. The Raman spectra show that this is not the case. Also the fact that catalytic activity for metathesis was observed for a coprecipitate of aluminum nitrate and ammonium metatungstate calcined at $823^{\circ} \mathrm{K}(3)$ is not a firm basis for the statement that aluminum tungstate is a reasonable precursor for the active site in metathesis, because, as shown here, the calcined coprecipitate used as a catalyst contained more than one tungsten compound. 
The conclusion that aluminum tungstate is not a major compound does not completely rule out the possibility that it is the catalytically active phase. Especially in metathesis it has been proven that the number of active sites is low (21, 22). Therefore, a priori, it is always possible that the precursor of the active site is a compound present in amounts below the detection limit.

This note can be summarized by the following conclusions :

(1) The formation of significant amounts of aluminum tungstate in tungsten oxide on $\gamma$-alumina catalysts of practical interest is improbable.

(2) The evidence reported in the literature for the formation of aluminum tungstate is not valid because of the impurity of the reference compounds used.

\section{ACKNOWLEDGMENTS}

Thanks are due to Dr. B. Koch and Mr. W. Molleman (Department of X-ray Spectrometry and Diffractometry, University of Amsterdam) for help in the interpretation and recording of the X-ray diffractograms, and to Mrs. M. C. MittelmeijerHazeleger for the TPR measurements. We also thank AKZO Chemie B.V. for a generous gift of $\gamma$-alumina. This study was supported by the Netherlands Foundation for Chemical Research (S.O.N.) with financial aid from the Netherlands Organization for the Advancement of Pure Research (Z.W.O.).

\section{REFERENCE}

1. Stork, W. H. J., Coolegem, J. G. F., and Pott, G. T., J. Catal. 32, 497 (1974).

2. Pott, G. T., and Stork, W. H. J., in "Preparation of Catalysts" (B. Delmon, P. A. Jacobs, and G. Poncelet, Eds.), p. 537. Elsevier, Amsterdam, 1976.

3. Stork, W. H. J., and Pott, G. T., Recl. Trav. Chim. Pays-Bas 96, M105 (1977).

4. Thomas, R., Moulijn, J. A., and Kerkhof, F. P. J. M., Recl. Trav. Chim. Pays-Bas 96, M134 (1977).

5. Iannibello, A., Marengo, S., Trifird, F., and Villa, P. L., in "Scientific Bases for the Preparation of Heterogeneous Catalysts," Second Int. Symposium, Louvain-la Neuve 1978, preprint A5.

6. Knözinger, H., and Jeziorowski, H., J. Phys. Chem. 82, 2002 (1978).
7. Ashley, J. H., and Mitchell, P. C. H., J. Chem. Soc. $A$ (1969), 2730.

8. Richardson, J. T., Ind. Eng. Chem. Fund. 3, 154 (1964).

9. De Beer, V. H. J., Van der Aalst, M. J. M., Machiels, C. J., and Schuit, G. C. A., J. Catal. 43, 78 (1976).

10. Lipsch, J. M. J. G., and Schuit, G. C. A., J. Catal. 15, 163, 174, 179 (1969).

11. Krylov, O. V., and Margolis, L. Ya., Kinet. Katal. 11, 358 (1970).

12. Asmolov, G. N., and Krylov, O. V., Kinet. Katal. 11, 847 (1970).

13. Sonnemans, J., and Mars, P., J. Catal. 31, 209 (1973).

14. Giordano, N., Padovan, N., Vaghi, A., Bart, J. C. J., and Castellan, A., J. Catal. 38, 1 (1975).

15. Brown, F. R., Makovsky, L. E., and Rhee, K. H., J. Catal. 50, 162 (1977).

16. Medema, J., Van Stam, C., De Beer, V. H. J., Konings, A. J. A., and Koningsberger, D. C., J. Catal. 53, 386 (1978).

17. Payen, E., Barbillet, J., Grimblot, J., and Bonnelle, J. P., Spectrosc. Lett. 11, 997 (1978).

18. Kerkhof, F. P. J. M., Mittelmeijer-Hazeleger, M. C., and Moulijn, J. A., to be published.

19. Craig, D. C., and Stephenson, N. C., Acta Crystallogr. B24, 1250 (1968).

20. De Boer, J. J., Acta Crystallogr. B30, 1878 (1974).

21. Westhoff, R., and Moulijn, J. A., J. Catal. 46, 414 (1977).

22. De Vries, J. L. K. F., and Pott, G. T., Recl Trav. Chim. Pays-Bas 96, M115 (1977).

$$
\begin{aligned}
& \text { R. Thomas } \\
& \text { F. P. J. M. Kerkhof } \\
& \text { J. A. MouliJn }
\end{aligned}
$$

Institute for Chemical Technology

University of Amsterdam

Amsterdam, The Nelherlunds

J. Medema

Prins Maurits Laboratory

National Defence Research Organization, T.N.O.

Rijswijk, The Netherlands

V. H. J. DE BEER

Laboratory of Inorganic Chemistry and Catalysis

Eindhoven University of Technology

Eindhoven, The Netherlands

Received February 23, 1979; revised June 19, 1979 